\section{Identification of a novel germplasm (Jor Lab L-9) of lemon grass (Cymbopogon khasianus) rich in methyl eugenol}

\author{
Mohan Lal ${ }^{1 *}$, Sunita Munda ${ }^{1}$, Sukriti Dutta ${ }^{1}$ and Sudin Kumar \\ Pandey ${ }^{1}$
}

\begin{abstract}
A new strain of Cymbopogon khasianus rich in methyl eugenol was identified and named Jor Lab L-9. It is stable for production of essential oil yield (average 0.81\%; $\sigma^{2} d i=0.00$ ) and methyl eugenol (average $74.56 \% ; \sigma^{2} d i$ $=0.06)$. This variety was registered with ICAR-NBPGR, New Delhi, India, under registration number INGR-18037.
\end{abstract}

Keywords: Cymbopogon khasianus, essential oil quality, methyleugenol.

\section{INTRODUCTION}

Species of the Cymbopogon genus are important and valuable medicinal and aromatic crops in the Poaceae family. They are cultivated in parts of Asia, America, and Africa (Lal 2018). Essential oil is extracted from Cymbopogon species by the steam distillation method, and this oil is used in perfumery, soap, cosmetics, floor cleaner and flavouring industries throughout the world (Dutta et al. 2017, Baruah et al. 2017). Different chemical constituents,viz., methyl eugenol, myrcene, geraniol, elemicin, citral, linalool, geranyl acetate, methyl isoeugenol, etc., are present in the essential oils of this genus (Dutta et al. 2016, Dutta et al. 2017). Among them, methyl eugenol, an important chemical constituent belonging to the phenylpropanoid group, is found in different spices, vegetables, and herbs (Linchtenstein and Casida 1963). This chemical can be converted to either elemicin or myristicin, a highly valuable compound (Koezuka et al. 1986). Methyl eugenol is used for flavour in baked confectionery products, non-alcoholic beverages, condiments, and hard and soft candy at a concentration level < 50 ppm (Hall and Oser 1965); in processed food; in perfumery; and in aromatherapy (Tan and Nishida 2012). A mixture of methyl eugenol and cuelure at different concentrations in Male Annihilation Techniques (MAT) has been used to control pests in Taiwan and Okinawa through their effectiveness against Bactocera dorsalis and Bactocera curcubitae (Vargas et al. 2000). Methyl dopa, an important hypertensive medication, can be synthesized from methyl eugenol (Robinson and Barr 2006, Kumaran et al. 2013). The various uses of methyl eugenol in the flavouring, perfumery, and pharmaceutical industries and the lack of availability of a $C$. khasianus strain rich in this substance highlights the importance of identification, for the first time, of a high methyl eugenol (74.56\%) rich variant from the $C$. khasianus germplasm collection. The genotype by environment interaction should always be evaluated for the release of any new variety (Agahi et al. 2020). Stability tests on the performance of this strain
Crop Breeding and Applied Biotechnology 20(3): e320720315, 2020 Brazilian Society of Plant Breeding. Printed in Brazil http://dx.doi.org/10.1590/198470332020v20n3c49

\footnotetext{
*Corresponding author: E-mail: drmohanlal80@gmail.com (iD) ORCID: 0000-0001-6995-3377
}

Received: 27 April 2020 Accepted: 11 July 2020 Published: 28 August 2020

${ }^{1}$ CSIR-North East Institute of Science and Technology, Biological Science and Technology Division, Medicinal, Aromatic and Economic Plant Group, Jorhat, Assam, 785-006, India 
identified as rich in methyl eugenol have been conducted over the years in multiple locations.

\section{BREEDING METHOD}

Two hundred seventy-two (272) accessions of lemon grass were collected throughout the states of Northeast India (viz., Manipur, Assam, Meghalaya, and Nagaland) in the year 2013 and were planted, with three replications, on 8 November, 2013, in a randomized complete block design (RCBD) in a $4 \times 3 \mathrm{~m}$ plot size, with plant-to-plant and rowto-row spacing of $60 \times 60 \mathrm{~cm}$ at the CSIR-NEIST, Jorhat experimental research farm in a selection trial. All the materials planted were authenticated by a taxonomist of the Botanical Survey of India, Shillong, Meghalaya (vide letter No.BSI/ ERC/Tech/2015/448), and voucher specimens were prepared and kept at the Department herbarium of the CSIR-NEIST Jorhat. All the morphological and chemical data for all the planted germplasm were recorded in triplicates during 201314 and 2014-15 in selection trials (Table 1). The first harvest was made 4.5 months after planting, and then the crops were harvested at an interval of every 3 months.

After evaluation of the experimental data for two years, a methyl eugenol-rich genotype was identified, which was named Jor Lab L-9. Multi-location trials (MLT) were conducted for this genotype, along with the C. khasianus RRLJM-637 (IC 0626782) and C. flexuosus (Jor Lab L-2) check varieties, at four locations in Northeast India [viz., Pasighat (Arunachal Pradesh), Imphal (Manipur), Jorhat (Assam), and Lakhmijan (Assam)] for three crop years (2015-16, 2016-17, and 2017-18). All the morphological and chemical data of the germplasm planted in each location were recorded using five replications, as per standard protocol (Lal et al. 2018). Stability analyses of the germplasm were analysed using the Eberhart and Russell (1966) model.

Essential oil was isolated using the Clevenger apparatus, in which $300 \mathrm{~g}$ samples of leaves from each C. khasianus germplasm were hydro distilled for three and half hours in $2.5 \mathrm{~L}$ of water (Guenther 1950), with three replications. After extraction, the essential oil was dried over anhydrous $\mathrm{Na}_{2} \mathrm{SO}_{4}$ and was stored in glass vials at 4 으.

GC/FID analysis of the essential oil was performed using an Agilent Technologies gas chromatograph model no. 6890 fused with a HP-5MS capillary column ( $30 \mathrm{~m} \times 0.25 \mathrm{~mm}$ i.d., $0.25 \mu \mathrm{m}$ film thickness). GC/MS analysis was performed on an Agilent Technologies gas chromatograph coupled to a mass selective detector MSD 5975C using a fused silica capillary HP-5MS column ( $30 \mathrm{~m} \times 0.25 \mathrm{~mm}$ i.d.; film thickness 0.25 $\mu \mathrm{m})$. The components were identified by matching their mass spectra value to the Wiley mass spectral/NIST library, which was then confirmed by comparison with retention indices on the HP-5MS column (Khan et al. 2016). The concentration of the identified compounds was directly calculated from peak areas.

Stability analysis of eight essential traits, viz., flowering plant height, vegetative plant height, number of tillers/ bush, number of internodes, number of nodes, essential oil yield, herbage yield, and methyl eugenol (\%) was performed using the Indostat statistical software, version 8.2. The Eberhart and Russel (1966) method was used to interpret the regression coefficient (bi), and deviation from the regression coefficient $\left(\sigma^{2} d i\right)$ was used to check stability.

\section{PERFORMANCE CHARACTERISTICS}

Different agronomical data were recorded for all the collected C. khasianus germplasm for two years (2013-14 and 2014-15) in selection trials, which led to identification of a methyl eugenol rich strain. The line identified achieved herbage yield of 29.50 tones ha $^{-1}$ year ${ }^{-1}$ and average essential oil yield of $0.81 \%$ (Table 2 ). It had previously been reported

Table 1. Range of different agronomic traits and essential oil percent in the collected $C$. khasianus germplasm

\begin{tabular}{lcc}
\hline Sl.No. & Trait & Range \\
\hline 1 & Vegetative plant height $(\mathrm{cm})$ & $69-143$ \\
2 & Flowering plant height $(\mathrm{cm})$ & $91-250$ \\
3 & Number of tillers bush ${ }^{-1}$ & $87-92$ \\
4 & Number of leaves & $485-526$ \\
5 & Length of lamina $(\mathrm{cm})$ & $56-73$ \\
6 & Breadth of leaf $(\mathrm{cm})$ & $0.4-0.8$ \\
7 & Length of basal sheath $(\mathrm{cm})$ & $12-34$ \\
8 & Length of ligule $(\mathrm{cm})$ & $0.1-0.5$ \\
9 & Length of auricle $(\mathrm{cm})$ & $0.09-0.1$ \\
10 & Colour of leaf sheath & Brownish green \\
11 & Number of nodes & $4-12$ \\
12 & Number of internodes & $3-11$ \\
13 & Diameter of nodes $(\mathrm{cm})$ & $1-2.20$ \\
14 & Diameter of internodes $(\mathrm{cm})$ & $0.50-1.20$ \\
15 & Length of internodes $(\mathrm{cm})$ & $16-27.70$ \\
16 & Length of spike $(\mathrm{cm})$ & $78.20-110.50$ \\
17 & Number of spikelets & $7-12$ \\
18 & Length of awn $(\mathrm{cm})$ & $0.70-1.10$ \\
19 & Flowering time & last week of October to \\
20 & Herbage Yield (tones ${ }^{-1}$ ha- ${ }^{-1}$ year ${ }^{-1}$ ) & 18.3 to 36.4 \\
21 & Essential oil $(\%)$ & $0.5-0.85$ \\
\hline 22 & Methyl eugenol $(\%)$ & $2-77$ \\
\hline
\end{tabular}


that fresh leaves of $C$. khasianus through hydro distillation has essential oil content of $0.70 \%$ (Choudhury 1995).

The GC/FID and GC/MS analysis of Jor Lab L-9 essential oil from multi-location trials of Jorhat in the 2017-18 crop year showed a total of 25 peaks, in which methyl eugenol was the major compound, with a concentration of $74.23 \%$, followed by $\beta$-myrcene (14.28\%), elemicin (1.65\%), cis- $\alpha$ bergamotene (1.19\%), and $\beta$-pinene (1.11\%) (Table 3). The average methyl eugenol content of the multi-location trial was found to be $74.56 \%$. However, a study on essential oil of C. khasianus from NE India showed the presence of geraniol (83\%) as the major compound (Lal et al. 2019). Moreover, a recent study was also conducted on C. khasianus collected from the Meghalaya region of Northeast India, where elemicin (70\%) was the major component (Lal et al. 2018), which is different from our study.

The germplasm identified (Jor Lab L-9) was planted in four locations of Northeast India (Jorhat, Imphal, Pasighat, and Lakhimijan). Since no methyl eugenol-rich variety has been available until now, the RRLJM-637 variety, with methyl

Table 3. GC/MS analysis of essential oil of C. khasianus (Jor Lab L-9) grown in Jorhat in multi-location trials

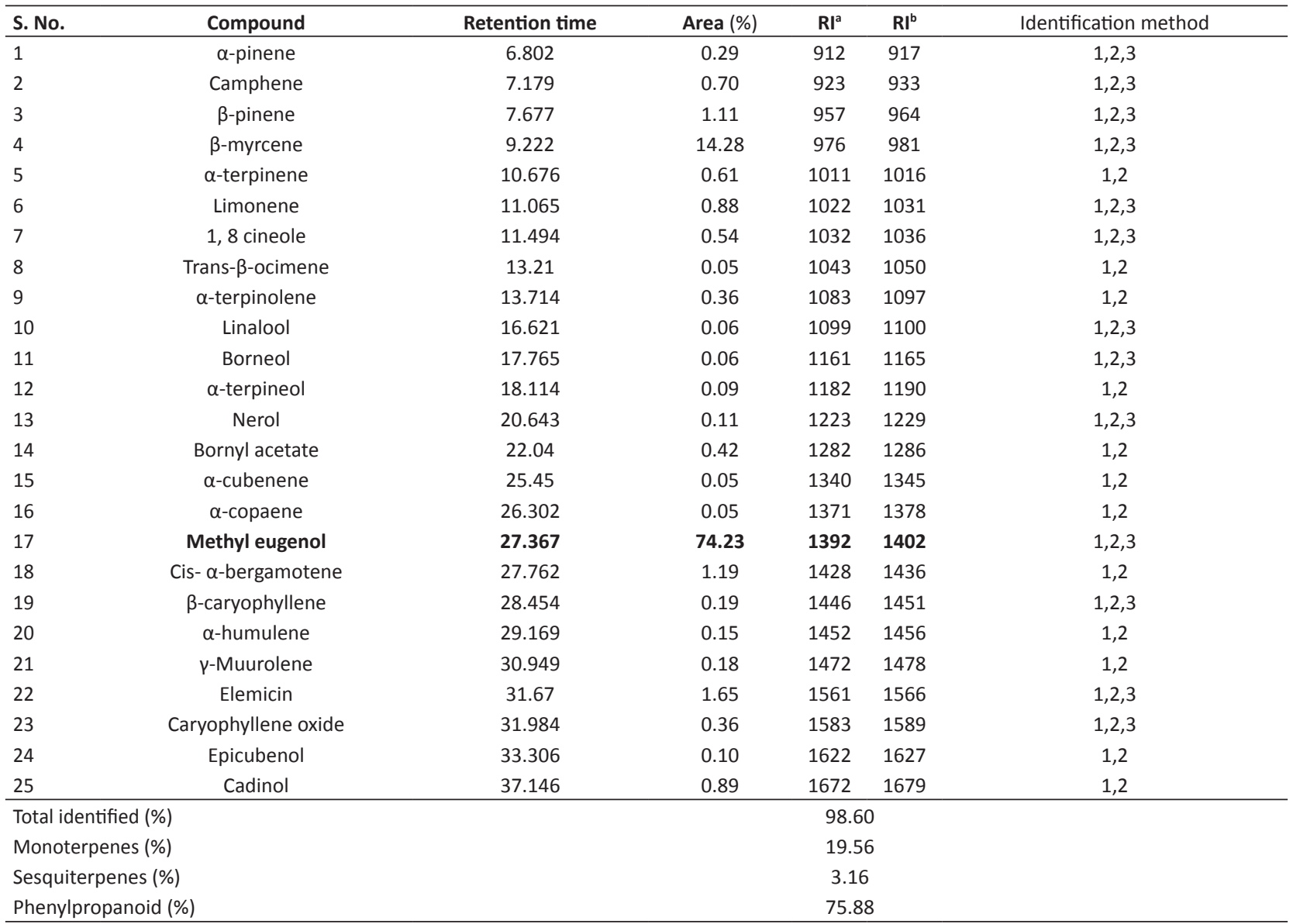

${ }^{\mathrm{a}} \mathrm{RI}=$ Experimental retention index; ${ }^{\mathrm{b}} \mathrm{RI}=$ Literature retention index; ${ }^{*}$ Identification methods: 1 . Comparison of retention indices with the literature; 2 . Comparison of the mass spectra with the mass libraries; 3 . Standards, by comparing retention time with the same GC condition.

** Khan et al. (2016). 
eugenol content of $25 \%$, and Jor Lab L-2, rich in citral, were planted to compare their data with the methyl eugenol-rich variety identified. The multi-location trials were conducted and recorded for the 2015-16, 2016-17, and 2017-18 crop years (Table 4). Stability analysis of the identified variety along with the check varieties revealed maximum means values of Jor Lab L-9 for all the traits, except vegetative plant height (Table 5). Jor Lab L-9 has a bi > 1 for the traits herbage yield, methyl eugenol (\%), number of nodes, and number of internodes. The smallest deviation from regression was seen in the essential oil yield trait $\left(\sigma^{2} d i=0.00\right)$, followed by methyl eugenol content $\left(\sigma^{2} d i=0.06\right)$, indicating that it is a stable and desirable trait. Eberhart and Russell (1966) stated that a genotype is stable if it has high mean performance, a regression coefficient equal to $1(b i=1)$, and deviation from regression $\left(\sigma^{2} d i\right)$ as low as possible. Similarly, the traits of herbage yield $\left(\sigma^{2} d i=0.41\right)$, number of nodes $\left(\sigma^{2} d i=0.19\right)$, and number of internodes $\left(\sigma^{2} d i=0.46\right)$ were found to maintain moderate consistency in the respective environment (Tables 5 and 6 ). The stability and high yield of germplasm forms the basis of a successful breeding programme, leading to development of a superior progeny (Munda et al. 2020).

Table 4. Agronomic and essential oil quality data of the $C$. khasianus genotype Jor Lab L-9 under multi-location trials in the 2015-16, 2016-17, and 2017-18 crop years (pooled data)

\begin{tabular}{|c|c|c|c|c|c|c|c|c|c|c|c|}
\hline $\begin{array}{l}\text { Sl. } \\
\text { No. }\end{array}$ & $\begin{array}{l}\text { Var } \\
\text { Loca }\end{array}$ & & $\begin{array}{l}\text { Vegetative } \\
\text { plant } \\
\text { height }(\mathrm{cm})\end{array}$ & $\begin{array}{c}\text { Flowering } \\
\text { plant } \\
\text { height }(\mathrm{cm})\end{array}$ & $\begin{array}{c}\text { Number } \\
\text { of tillers } \\
\text { bush }^{-1}\end{array}$ & $\begin{array}{l}\text { Number } \\
\text { of nodes }\end{array}$ & $\begin{array}{l}\text { Number of } \\
\text { internodes }\end{array}$ & $\begin{array}{l}\text { Herbage } \\
\text { Yield } \\
\text { (tonnes } \\
\text { ha }^{-1} \text { year }^{-1} \text { ) }\end{array}$ & $\begin{array}{l}\text { Oil \% } \\
(v / w)\end{array}$ & $\begin{array}{l}\text { Methyl } \\
\text { eugenol } \\
(\%)\end{array}$ & $\begin{array}{c}\text { Major } \\
\text { oil } \\
\text { constituent }\end{array}$ \\
\hline \multirow{3}{*}{1} & \multirow{3}{*}{ Jor Lab L-9 } & Imphal & 108.66 & 219.55 & 95.60 & 12.47 & 11.33 & 28.78 & 0.81 & 72.77 & \multirow{3}{*}{$\begin{array}{l}\text { Methyl } \\
\text { eugenol }\end{array}$} \\
\hline & & Pasighat & 111.56 & 238.17 & 95.13 & 14.67 & 13.73 & 29.57 & 0.82 & 74.60 & \\
\hline & & Lakhmijan & 112.29 & 227.12 & 99.07 & 13.60 & 12.47 & 29.81 & 0.81 & 75.90 & \\
\hline \multirow{5}{*}{2} & \multirow{5}{*}{$\begin{array}{l}\text { RRLJM-637 } \\
\text { (IC0626782) }\end{array}$} & Jorhat & 104.17 & 177.65 & 55.13 & 11.73 & 11.07 & 22.16 & 0.38 & 25.75 & \multirow{5}{*}{$\begin{array}{l}\text { Methyl } \\
\text { eugenol }\end{array}$} \\
\hline & & Imphal & 103.05 & 189.09 & 59.87 & 12.00 & 10.93 & 21.59 & 0.38 & 25.99 & \\
\hline & & Pasighat & 105.94 & 192.92 & 58.40 & 14.20 & 13.20 & 21.55 & 0.39 & 25.87 & \\
\hline & & Lakhmijan & 109.87 & 202.55 & 61.00 & 12.73 & 11.73 & 21.99 & 0.39 & 25.40 & \\
\hline & & Avg & 105.76 & 190.55 & 58.60 & 12.66 & 11.73 & 21.83 & 0.39 & 25.76 & \\
\hline \multirow{3}{*}{3} & & Avg & 111.22 & 189.48 & 55.95 & 12.81 & 12.18 & 21.20 & 0.40 & 3.73 & Citral \\
\hline & & $S E(m)$ & 1.64 & 13.43 & 12.77 & 0.16 & 0.15 & 2.67 & 0.14 & 20.93 & \\
\hline & & $\mathrm{CV}$ & 2.60 & 11.43 & 31.60 & 2.16 & 2.11 & 19.13 & 44.93 & 104.51 & \\
\hline
\end{tabular}

Table 5. Estimation of mean and stability parameters of vegetative plant height, herbage yield, essential oil yield, methyl eugenol (\%), and flowering plant height in MLT trials

\begin{tabular}{|c|c|c|c|c|c|c|c|c|c|c|c|c|c|c|c|}
\hline \multirow[b]{2}{*}{ Genotypes } & \multicolumn{3}{|c|}{ Vegetative plant height } & \multicolumn{3}{|c|}{ Herbage yield } & \multicolumn{3}{|c|}{ Essential oil yield } & \multicolumn{3}{|c|}{ Methyl eugenol (\%) } & \multicolumn{3}{|c|}{ Flowering plant height } \\
\hline & $\mu$ & $\beta i$ & $\sigma^{2} d i$ & $\mu$ & $\beta i$ & $\sigma^{2} d i$ & $\mu$ & $\beta i$ & $\sigma^{2} d i$ & $\mu$ & $\beta i$ & $\sigma^{2} d i$ & $\mu$ & $\beta i$ & $\sigma^{2} d i$ \\
\hline Jor Lab L-9 & 109.8 & 0.57 & $5.82 * *$ & 29.51 & 1.43 & 0.41 & 0.81 & 0.57 & 0.00 & 74.56 & 1.13 & 0.06 & 230.3 & $-0.12 * *$ & $107.15^{* * *}$ \\
\hline RRLJM-637 & 105.8 & 1.19 & $16.57^{* * *}$ & 21.83 & 0.93 & 0.42 & 0.39 & 0.33 & 0.00 & 25.76 & 1.17 & $1.43^{* * *}$ & 190.6 & 0.89 & $279.89 * * *$ \\
\hline Jor Lab L 2 & 111.2 & 1.23 & $29.97 * * *$ & 21.20 & 0.64 & 0.23 & 0.40 & 2.10 & 0.00 & 3.73 & $0.22 *$ & -0.01 & 189.5 & $2.23 *$ & $267.14^{* * *}$ \\
\hline Population mean & \multicolumn{3}{|c|}{108.9} & \multicolumn{3}{|c|}{24.18} & \multicolumn{3}{|c|}{0.53} & \multicolumn{3}{|c|}{34.68} & \multicolumn{3}{|c|}{203.4} \\
\hline
\end{tabular}

* Significant at $P=0.05, * *$ Significant at $P=0.01, * * *$ Significant at $P=0.005$.

Table 6. Estimation of mean and stability parameters of number of tillers bush ${ }^{-1}$, number of nodes, and number of internodes in MLT trials

\begin{tabular}{|c|c|c|c|c|c|c|c|c|c|}
\hline \multirow[b]{2}{*}{ Genotypes } & \multicolumn{3}{|c|}{ Number of tillers bush ${ }^{-1}$} & \multicolumn{3}{|c|}{ Number of nodes } & \multicolumn{3}{|c|}{ Number of internodes } \\
\hline & $\mu$ & $\beta i$ & $\sigma^{2} d i$ & $\mu$ & $\beta i$ & $\sigma^{2} d i$ & $\mu$ & $\beta i$ & $\sigma^{2} d i$ \\
\hline Jor Lab L-9 & 95.53 & 0.44 & $21.36 * * *$ & 13.20 & 1.54 & 0.19 & 12.16 & 1.50 & 0.46 \\
\hline RRLJM637 & 58.60 & 0.70 & $26.09 * * *$ & 12.66 & 1.07 & 0.05 & 11.73 & 1.08 & 0.02 \\
\hline Jor Lab L 2 & 55.95 & 1.85 & $26.50 * * *$ & 12.81 & 0.39 & 0.29 & 12.18 & 0.41 & $0.64 *$ \\
\hline Population mean & \multicolumn{3}{|c|}{70.03} & \multicolumn{3}{|c|}{12.89} & \multicolumn{3}{|c|}{12.02} \\
\hline
\end{tabular}

*Significant at $P=0.05, * *$ Significant at $P=0.01, * * *$ Significant at $P=0.005$. 


\section{GERMPLASM REGISTRATION AND DISTRIBUTION}

This is the first report of a methyl eugenol-rich strain of lemon grass identified through a pure line plant breeding method. The variety was registered with ICAR-NBPGR, New Delhi (vide registration number INGR-18037), and planting material is available for commercial cultivation. Two agro-based industries have been created for commercial cultivation, and planted area is more than 42 ha in different regions of India.

\section{ACKNOWLEDGEMENTS}

The authors are thankful to the director of CSIR-NEIST, Jorhat for providing the necessary experimental field and laboratory facilities. Special thanks to Branch Laboratory, CSIR-NEIST Imphal and CAU, CHFS Pasighat for help in conducting the multi-location field trials in their respective locations. This study was funded by CSIR, New Delhi in the form of the CSIR network projects BSC-0110 and HCP-0007.

\section{REFERENCES}

Agahi K, Ahmadi J, Oghan HA, Fotokian MH and Orang SF (2020) Analysis of genotype $x$ environment interaction for seed yield in spring oilseed rape using the AMMI model. Crop Breeding and Applied Biotechnology 20: e26502012.

Baruah J, Gogoi B, Das K, Ahmed NM, Sarmah DK, Lal M and Bhau BS (2017) Genetic diversity study amongst Cymbopogon species from NE-India using RAPD and ISSR markers. Industrial Crops and Products 95: 235-243.

Choudhury SN (1995) Essential oil of Cymbopogon khasianus (Munro ex Hack.) Bor from Northeastern India. Journal of Essential Oil Research 7: 555-556.

Dutta S, Munda S, Chikkaputtaiah C and Lal M (2017) Assessment of selection criteria for development of high yielding genotypes using variability parameters in lemon grass Cymbopogon flexuosus $\mathrm{L}$. Journal of Essential Oil Bearing Plants 20: 1450-1460.

Dutta S, Munda S, Lal M and Bhattacharyya PR (2016) A short review on chemical composition, therapeutic use and enzyme inhibition activities of Cymbopogon species. Indian Journal of Science and Technology 9: 1-9.

Eberhart SA and Russell WW (1966) Stability parameters for comparing varieties. Crop Science 6: 36-40.

Guenther E (1950) The essential oils. D Van Nostrand Company, New York, p. 20-25.

Hall R and Oser BL (1965) Recent progress in the consideration of flavouring ingredients under the food additives amendment III. GRASS substances. Food Technology 19: 151-197.

Khan M, Al-Saleem MSM and Al Khathlan HZ (2016) A detailed study on chemical characterization of essential oil components of two Plectranthus species grown in Saudi Arabia. Journal of Saudi Chemical Society 20: 711.

Koezuka Y, Honda G and Tabata M (1986) Genetic control of phenylpropanoids in Perilla frutescens. Phytochemistry 25: 20852087.
Kumaran N, Balagawi S, Schutze MK and Clarke AR (2013) Evolution of lure response in tephritid fruit flies: phytochemicals as drivers of sexual selection. Animal Behaviour 85: 781-789.

Lal M (2018) Jor Lab L-8(IC0619026; INGR16020), a lemon grass (Cymbopogon flexuosus) germplasm with high herbage yield with high essential oil content. Indian Journal of Plant Genetic Resource 31: 117.

Lal M, Borah A and Pandey SK (2019) Identification of a new high geraniol rich variety "Jor Lab L-15" of lemongrass [Cymbopogon khasianus (Hack) Stapf (ex Bor)]. Journal of Essential Oil Bearing Plants22: 972-978.

Lal M, Dutta S, Munda S and Pandey SK (2018) Novel high value elemicinrich germplasm of lemon grass (Cymbopogon khasianus (Hack) Stapf (ex Bor) from North East India. Industrial Crops and Products 115: 98-103.

Linchtenstein EP and Casida JE (1963) Myristicin, an insecticide and synergistic occurring naturally in the edible part of parsnips. Journal of Agricultural and Food Chemistry 11: 410- 415.

Munda S, Sarma N and Lal M (2020) G $\times$ E interaction of 72 accessions with three year evaluation of Cymbopogon winterianusJowitt. using regression coefficient and Additive Main effects and Multiplicative Interaction model (AMMI). Industrial Crops and Products 146: 112169.

Robinson SH and Barr DB (2006) Use of bio monitoring data to evaluate methyl eugenol exposure. Environmental Health Perspectives 114: 1797-1801.

Tan KH and Nishida R (2012) Methyl Eugenol: Its occurrence, distribution, and role in nature, especially in relation to insect behaviour and pollination. Journal of Insect Science 12: 1-60.

Vargas RI, Stark JD, Kido MH, Ketter HM and Whiteh LC (2000) Methyl eugenol and cue-lure traps for suppression of male oriental fruit flies and melon flies (Diptera: Tephritidae) in Hawaii: effects of lure mixtures and weathering. Journal of Economic Entomology 93: 81-87.

(c) EY This is an Open Access article distributed under the terms of the Creative Commons Attribution License, which permits unrestricted use, distribution, and reproduction in any medium, provided the original work is properly cited. 